\title{
Researching gender and law enforcement as public health input
}

\author{
Melissa Jardine*,†
}

In western developed countries women make up approximately 20 per cent of the police workforce. Estonia boasts the highest proportion of female officers with 33 per cent (Resetnikova, 2006), while among the lowest is Pakistan with fewer than 1 per cent (Peters, 2014). These figures show that the extent of women's inclusion in policing is globally disparate, but why is this so and does it matter? Policing is traditionally held up as a male occupation due to perceived necessity of physical strength, though many studies have rejected the view that effective policing requires the bodily authority associated with masculinity (Lonsway, 2000; Silvestri, 2003). Police agencies are under increasing pressure to be 'professional' and accountable to the whole community, including having a workforce which reflects the diversity of people they serve. Promoting and upholding an 'internal culture of mutual respect and fairness' can be seen as important ingredients in securing community support (Sutton, 1996). There is a range of circumstances which can propel women into law enforcement occupations, but these are not necessarily linear projects because they also relate to the status of women in broader society. Increasingly, it is recognized that policy transfer or export has unevenly travelled from Global North to South (Carrington, Hogg, Sozzo, 2015; Connell, 2007), sometimes with poor outcomes or unintended consequences. The nature of, and prospects for, women's integration in policing, their rights and safety, thus, rely on strategies both inside and outside the police organization and appropriate for local circumstances.

Whilst law enforcement has not usually been perceived to have an explicit public health role, there has recently been growing interest in the many ways in which law enforcement, especially police, contribute to the public health mission (Van Dijk \& Crofts, 2017). Looking at a specific policehealth nexus, women's participation in policing has shown benefits associated with responsiveness to-and reduction of-gender-based violence (Miller \& Segal, 2016). Women officers are also less likely to use excessive force (Lonsway, 2000; Porter \& Prenzler, 2017; Schuck \& Rabe-Hemp, 2007). Thus, the presence of police women can have dual effects on public health: firstly, as protectors who prevent violence in the community, and secondly, as less inclined to be perpetrators of violence in their official capacity.
Within western liberal democracies, women have often pursued full integration (after a period of segregation) into policing, undertaking the same training and initial operational deployment as men. This approach relied on pioneering women who were prepared to publicly and overtly resist workplace segregation (Brown, 1997; Strobl, 2008), but this tactic is not globally uniform. Strobl (2008) argues the trajectory for women's integration in policing in the West coalesced around availability of legislation to litigate against gender discrimination and wider feminist movements in the 1960s. These dynamics enabled a 'cultural space' for dissent not necessarily available to women in some places. Strobl specifically mentions Muslim Arab contexts. That is not to say Muslim Arab women do not engage in 'politicking', but that it is done within certain cultural parameters which avoid overt confrontation and maintain the 'power and control associated with the male identity' (Strobl, 2008, p. 55).

Despite some universalities, there are different policing paradigms with distinctive systems and cultural differences (Van Dijk, Hoogewoning, \& Punch, 2015). Subsequently, there are different drivers for women's inclusion in policing and the nature of their inclusion. In some cases, it is to address the needs of women in the community (for example, gender-based violence and Women's Police Stations in Brazil) (Hautzinger, 2002); in others, a broader top-down government push for gender equality and equal opportunity (see postConfucian Taiwan) (Gingerich \& Chu, 2013), or as a response to public criticism, as in the aftermath of the Nirbhaya gang-rape case in 2012 which instigated reforms in the Delhi Police (Khanikar, 2016). In the Ukraine, an unstable security environment has seen gender-sensitive police reform as a key driver for improving policing with a view to being an exemplar for gender equality community-wide (Weitenberg \& Grey, 2018).

Barriers to women's participation in policing also vary across different legal frameworks, local cultures, and institutional practices. For example, departmental policies compelling women to cut their hair to shorter than one inch prior to entering police training in Texas had differential effects on potential African-American applicants (Kringen, 2014). A lack of uniforms, lockable toilets and changing rooms, and exposure to sexual assault dissuades women from policing in Afghanistan (Hancock, 2013). In some instances,

Correspondence to: Melissa Jardine, Law School, University of New South Wales, Building F8, Union Road, UNSW Kensington Campus, Sydney NSW 2052, Australia.

Tel: +61 (0) 417374 070; E-mail: m.jardine@student.unsw.edu.au 
official policies, such as ceiling quotas, exist that make it more competitive for women than men to be selected (e.g., a maximum quota of 15\% females in Vietnam) (Bộ Công an, 2016, Article 3). In Turkey, a member of the police selection committee admitted to unsavoury methods to limit women's recruitment, saying, "In fact we do not want to recruit them, but officially we have no right to bar them. To make them unsuccessful, we ask some really illogical and difficult questions" (Caglar, 2004, p. 360). In Bahrain, the impact of social stigma on family and marriage prospects affects women's participation due to cultural parameters regarding religious identity (Strobl, 2008).

Whilst there are different models for women's inclusion in policing, recruitment and selection is only a first step. Retaining women in frontline police work can be difficult. An Australian study found that whilst in training, female police desired equal treatment to their male counterparts; however, after field experience, many policewomen became resigned to 'doing gender' or taking on functions perceived as peripheral to 'core' policing (Chan, Devery, \& Doran, 2003). A recent Australian review found that gender stereotyping, sexual harassment, and discrimination led to increased attrition of policewomen (Victorian Equal Opportunity and Human Rights Commission, 2017). Further, the fact policewomen in Brazil were specifically tasked with supporting female victims of violence did not prevent them from sometimes having derisory and cynical attitudes towards those they were supposed to help (Hautzinger, 2002). Indeed, policewomen sometimes take on masculine characteristics to fit into the male-dominated police culture and to broaden career opportunities (Rabe-Hemp, 2009). In Dehli, Khanikar (2016) maintains women's presence in a police organization itself is not enough to pursue an emancipatory objective if the organization continues to idealize 'manliness' entrenching the subjugation of women officers.

Of course, the police are a powerful institution and women should have equal opportunity to be involved at the highest levels in the decision-making processes that affect them. But fundamentally, women comprise 50 per cent of the population and so why shouldn't they be jointly responsible for community safety? However, the most effective way to get there varies. Strategies for women's inclusion in policing must take into consideration the varied structural conditions and individual needs of women whilst pursuing the larger goal of a universal gender equality and women's safety.

An important obstacle in designing context-specific strategies is that knowledge about policing has been produced and disseminated unevenly so that our understanding comes from a skewed emphasis on the western experience. Models for women's inclusion in policing in the Global North cannot neatly be transferred to suit the specificities of the Global South (arguably a colonial act itself, according to Strobl, 2008). Strobl argues for more empirical research to be undertaken in different political, social, and cultural contexts to provide evidence for which circumstances, variations, and alternatives are suitable, and that hybrid or 'two-track' system for women's integration into policing may be appropriate for some contexts (2008, pp. 55-56). Equally, the transportation of approaches to address gender-based violence from Global North to South has both questionable ethics and efficacy, and requires greater appreciation of local environs, structures, and cultures (DeKeseredy \& Hall-Sanchez, 2018; Walklate \& Fitz-Gibbon, 2018).

To address weaknesses in current theorizing of policing, a conceptual framework is needed to facilitate more nuanced understandings of the relationship between (but not limited to) gender in policing and public health. I suggest a framework for a southern policing perspective to enable exploration of variations and change in other policing cultures and practices outside the dominant western conceptual frameworks. I propose an extension of the interactive model of police culture and practice developed by Chan (1997; Chan et al., 2003) which draws on Bourdieu's (1990) conceptualizations of field and habitus as a relational dynamic. The framework is useful because it provides flexibility for explaining police practices in both northern and southern contexts. It can also account for differences in cultural knowledge and institutionalized practices. A southern policing perspective pays attention to variations in the field, including the historical relations of a particular place, its political system, broad societal culture, legal frameworks, organizations, relations between police and the community, and gender as a social institution. Reflexive consideration of these aspects of the structural environment (and their interaction, given they are not necessarily fixed and thus amenable to change) can promote better design and implementation of approaches inside and outside the police organization.

Fortunately there are platforms in place to further develop this agenda. For example, in 2018 two relevant international conferences will be held in Canada: the first is the International Association of Women Police's annual conference, 26-30 August, in Calgary, followed by the International Law Enforcement and Public Health (LEPH2018) Conference, 21-24 October, in Toronto. In particular, LEPH2018 purposefully seeks empirical research and program examples from the global South to highlight diversity of policing and public health approaches which are culturally contextualized. Whilst held separately, the conferences' goals are inextricably linked in their ambition to deliver a more holistic and community-based inclusive model to safety and well-being, law enforcement, and public health.

\section{ACKNOWLEDGMENTS}

Thanks to Professor Nick Crofts, Director of the Centre for Law Enforcement and Public Health, and, Auke van Dijk, Senior Strategist, Agora Police \& Security, Dutch Police Service, Amsterdam, Netherlands, for their comments on earlier versions of this paper.

\section{CONFLICT OF INTEREST DISCLOSURES}

The author declares there are no conflicts of interest.

\section{AUTHOR AFFILIATIONS}

*Law School, University of New South Wales, Sydney, NSW, Australia; ${ }^{\dagger}$ Centre for Law Enforcement and Public Health, Melbourne, Victoria, Australia.

\section{REFERENCES}

Bourdieu, P. (1990). In other words: Essays towards a reflexive sociology. Stanford, UK: Stanford University Press.

Brown, J. (1997). European policewomen: A comparative research perspective. International Journal of the Sociology of Law, 25(1), 1-19.

Caglar, A. (2004). Recruitment in the Turkish police. Policing and Society, 14(4), 348-364. doi:10.1080/1043946042000286065 
Carrington, K., Hogg, R., Sozzo, M. (2015). Southern criminology. British Journal of Criminology, 56(1), 1-20.

Chan, J.B.L. (1997). Changing Police Culture: Policing in a multicultural society. Cambridge, UK: Cambridge University Press.

Chan, J.B.L., Devery, C., \& Doran, S. (2003). Fair cop: Learning the art of policing. Toronto, ON: University of Toronto Press.

Bô Công an (2016). Quy đnh về tuyến sinh vào các trường Công an nhân dân. 15/2016/TT-BCA [Circular on Regulations on admission to the People's Police]. Hanoi, Vietnam: Ministry of Public Security. Retrieved from: https://thuvienphapluat.vn/van-ban/Giao-duc/Thong-tu-15-2016TT-BCA-tuyen-sinh-vao-cac-truong-cong-an-nhan-dan-306993.aspx

Connell, R. (2007). Southern theory: the global dynamics of knowledge in social science. Crows Nest, N.S.W., Australia: Allen \& Unwin.

DeKeseredy, W. S., \& Hall-Sanchez, A. (2018). Male violence against women in the Global South: What we know and what we don't know. In K. Carrington, R. Hogg, J. Scott, \& M. Sozzo (Eds.), The Palgrave handbook of criminology and the Global South (883-900). New York, NY: Palgrave Macmillan US.

Gingerich, T., \& Chu, D. (2013). Gender integration in policing: a comparison of male police recruits' receptiveness in Taiwan and the United States. Paper presented at the Annual Meeting of the Asian Association of Police Studies., Taipei, Taiwan, June 2013.

Hancock, L. (2013). Women and the Afghan police: Why a law enforcement agency that respects and protects females is crucial for progress. Oxford, UK: Oxfam International.

Hautzinger, S. (2002). Criminalising Male violence in Brazil's women's police stations: From flawed essentialism to imagined communities. Journal of Gender Studies, 11(3), 243-251. doi:10.1080/0958923022000021278

Khanikar, S. (2016). Women police in the City of Delhi: Gender hierarchies, 'pariah femininities' and the politics of presence. Studies in Indian Politics, 4(2), 159-177. doi:10.1177/2321023016665517

Kringen, A.L. (2014). Understanding barriers that affect recruiting and retaining female police officers: A mixed method approach (PhD Dissertation, Texas State University, San Marcos, TX). Retrieved from: https://digital. library.txstate.edu/handle/10877/5291

Lonsway, K. (2000). Hiring \& retaining more women: The advantages to law enforcement agencies. Los Angeles, CA: Feminist Majority Foundation, National Center for Women \& Policing.

Miller, A.R., \& Segal, C. (2016). Do female officers improve law enforcement quality? Effects on Crime Reporting and Domestic Violence (September 2016). Available from: https://papers.ssrn.com/sol3/ papers.cfm?abstract_id=2335990. doi:http://dx.doi.org/10.2139/ ssin. 2335990
Peters, A. (2014). POLICY BRIEF: The role of Pakistani policewomen in countering violent extremism. Washington, DC: Inclusive Security. Retrieved from https://www.inclusivesecurity.org/2014/03/31/ policy-brief-role-pakistani-policewomen-countering-violent-extremism/

Porter, L.E., \& Prenzler, T. (2017). Police officer gender and excessive force complaints: an Australian study. Policing and Society, 27(8), 865-883. doi:10.1080/10439463.2015.1114616

Rabe-Hemp, C.E. (2009). POLICEwomen or PoliceWOMEN?: Doing gender and police work. Feminist Criminology, 4(2):114-129.

Resetnikova, A. (2006). Women in policing in a transforming organization: The case of The Estonian Police. The Journal of Power Institutions in Post Soviet Societies, 4/5.

Schuck, A.M., \& Rabe-Hemp, C. (2007). Women police: The use of force by and against female officers. Women \& Criminal Justice, 16(4), 91-117. doi:10.1300/J012v16n04_05

Silvestri, M. (2003). Women in charge: Policing, gender and leadership. Cullompton, UK: Willan Publishing

Strobl, S. (2008). The Women's Police Directorate in Bahrain: An ethnographic exploration of gender segregation and the likelihood of future integration. International Criminal Justice Review, 18(1), 39-58.

Sutton, J. (1996). Keeping the faith: Women in policing - a New South Wales Perspective. Paper presented at The Australian Institute of Criminology Conference First Australasian Women Police Conference, Sydney, July 29-31. Canberra City, Australia: The Institute.

Van Diik, A. \& Crofts, N. (2017). Law enforcement and public health as an emerging field. Policing and Society, 27(3), 261-275.

Van Dijk, A., Hoogewoning, F., \& Punch, M. (2015). What matters in policing? Change, values and leadership in turbulent times. Bristol, UK: Policy Press, University of Bristol.

Victorian Equal Opportunity and Human Rights Commission. (2017) Independent review into sex discrimination and sexual harassment, including predatory behaviour, in Victoria Police-Phase 2 Audit. Carlton, Australia: the Commission.

Walklate, S., \& Fitz-Gibbon, K. (2018). Criminology and the violencels) of northern theorizing: A critical examination of policy transfer in relation to violence against women from the Global North to the Global South. In K. Carrington, R. Hogg, J. Scott, \& M. Sozzo (Eds.), The Palgrave handbook of criminology and the Global South. New York, NY: Palgrave MacMillan US.

Weitenberg, C., \& Grey, K. (2018, March 6). Officer llona reporting for duty. SBS News. Retrieved from: https://www.sbs.com.au/news/dateline/ story/officer-ilona-reporting-duty 